\title{
Participatory design in lean production: which contribution from employees? for what end?
}

\author{
M.S Perez Torallab, ${ }^{\text {ab, }}$, P. Falzon ${ }^{\mathrm{a}}$ and A. Morais ${ }^{\mathrm{b}}$ \\ ${ }^{a}$ Laboratory of Ergonomics, Centre de Recherche sur le Travail et le Développement, Conservatoire National des \\ Arts et Métiers, Paris, France \\ ${ }^{b}$ Ergonomics Department, PSA Peugeot Citroën, Pôle tertiaire, Poissy, France
}

\begin{abstract}
The proponents of lean production have pointed to the positive effects of the work organization on employees in terms of autonomy, enhanced skills and empowerment mainly by their participation into the continuous improvement of work process. But studies that have examined this issue suggest that the increase in autonomy is not sufficient to compensate for increases work intensity. Participatory design has grown extensively in manufacturing since the 1980's under the impulsion of the Scandinavian socio-technical system approach and it's central in the model of lean production performance. Its main objectives are to improve quality, increase productivity and safety through employee's participation to the reduction of non-value added activities, such as defined by lean production. In the line of the studies on participatory design and continuous improvement the present study examines the functioning of work groups, based on the kaizen model, the aim of which was to improve the proportion of "value-added activities" and working conditions, essentially physical constraints. The main results are consistent with the literature and show that accelerated forms of re-conception activities give employees limited room for maneuver to elaborate solutions based on the analysis of the real activity. This study is part of a broader initiative that goes in the direction of continuous improvement of the design process itself so that it integrates the real constraints of work and propose changes bases on work as it actually takes place, beyond pre-established performance goals bases on the reduction of "non added value activities".
\end{abstract}

Keywords: Ergonomics, Lean management, participatory design, continuous improvement,

\section{Introduction}

Lean production principles have been conceptualized in the 1990's [1] from the Toyota Production System (TPS) and have become a benchmark in the automotive industry; its applications have spread to other sectors such as hospitals, information technology and the production of services in general. Lean production structures work process by four main principles: just-in-time production, automation (jido$k a$ ), standardization and continuous improvement (kaizen).

The relationships between lean production and ergonomics are today at the hearth of a discussion within the community of ergonomics [2, 3]. A major reason is that lean production pretends to naturally integrate ergonomics into its approach for instance via multi-skilling and the participation of employees to the continuous improvement process (kaizen). As Bourgeois and Gonon [2] pointed out, in the continuous improvement workshops the words of the operators and therefore the call of work are often buffeted by technical and industrial determinism that dominates the debate. The authors add that the difficulty to talk freely and effectively about what is their added value is obvious, especially when it corresponds to daily transgressions of standards or "best practices". In fact, lean production is an attempt to

\footnotetext{
* Corresponding author. E-mail: mariapereztoralla@gmail.com. Check if the checkbox in menu Tools/Options/Compatibility/Lay out footnotes like Word 6.x/95/97 is selected if you make a footnote for the corresponding author.
} 
reduce impediments to the smooth flow of production through continuous improvement (kaizen), and elimination of "wasted" time and motion (muda and muri) which are considered as non-value added activities [4]. Moreover, proponents of lean production argue that this production system, although it continually try to identify slack in the system, also provides workers with the skills they need to control their work environment and the continuing challenge of making the work go more smoothly [1].

This paradox between participatory approaches in lean production and ergonomics is at the center of this study. The automotive company where this study was carried out developed its specific production system based on principles of lean production such as: value stream mapping definition, pull system, visual management, and continuous improvement involving operators (kaizen). The analysis focused on the functioning of work groups (based on the kaizen model), the aim of which was to improve the proportion of "value-added activities" and working conditions (essentially physical constraints) as defined by lean production and more specifically on the role and contribution of the operators to the work process performance.

\section{Participatory design in lean production and ergonomics}

\subsection{Issues on participatory design in lean production}

Participatory design has grown extensively in manufacturing since the 1980's under the impulsion of the Scandinavian socio-technical system approach. Participation may take different forms: quality circles, TQM (total quality management), kaizen groups (continuous improvement), semi-autonomous groups etc. But the main objectives of employees' participation are similar and seek to improve quality, increase productivity and safety. Work organizations such as learning organizations or Lean production Womack et al. [1] are characterized, unlike strictly taylorist organizations, by the fact that they explicitly demand that employees contribute to the redesign of production situations [5]. Along with Scandinavian sociotechnical systems (STS), Lean production have been extolled as reforms of taylorism and the traditional assembly line approach to job design [6]. According to Womack et al. [1] one of the two key organizational features of the truly lean plant is "the transfer of the maximum number of tasks and responsibilities to those workers actually adding value to the car on the line" (p.99). However, employee participation is much more constrained in Lean organizations than in learning organizations. In the former, the objectives of the redesign situations are a priori specified (suppression of supposedly "non added value activities", reduction of personnel and prescription of an "optimal" procedure). Work conditions may also be taken into account, but only in a limited perspective: elimination of physical constraints. Cognitive constraints, time pressure, limitations to autonomy are not considered. Furthermore, Saurin and Ferreira [7] highlighted the increased responsibilities, the accelerated pace of work and pressure related to participation in quality circles as potential stressors.

This tendency is even more present in derivate forms of kaizen (continuous improvement) that is "Kaizen Blitz" or "Kaizen flash" described by various authors [8, 9, 3] as an accelerated form of kaizen where the objective is to find the solution for predetermined production problems in only a few days. The authors point out that in the organizations adopting these practices, the predefined objectives (diminution of work space, time compression, walking limitations, reduction of movements) cannot be discussed and employees have limited room for maneuver to elaborate solutions based on the analysis of their activity.

Gough and Fastenau [10] conducted a literature review on the team concept and the commitment of employees to the continuous improvement of work process in Japanese North American transplants (table 1). The author's review shows that in four of the five companies studied there is a gap between the ideology and the practice of the team concept. For example, in CAMI Suzuki/GM joint venture, the kaizen concept is central to the ideology that employees are empowered to participate in the lean production system but in practice $84 \%$ of employees (survey) considered that teams did not encourage commitment to the company. Management responses to kaizen suggestions were perceived by employees as resulting in them having to work harder rather than smarter.

\subsection{Ergonomics approach on participatory design}

Ergonomic studies have emphasized the potential benefits of user participation in system design $[11,12$, 13] in terms of consideration to a larger number of factors including quality, ease of use of technical devices, limitation of errors, enhanced understanding of the task, competence development. However these potential benefits suppose specific conditions in or- 
der to become real, in terms of objective and methodology of participation actions. As Darses [14] pointed out, the continuous design of production system is not new in manufacturing (for instance quality circles have appeared in Japan since the 1960s), what is new is the rapidity of the readjustment required by the evolution of the demand and techniques. A real effort of organization and systematization of continuous design actions is then needed. The author identified three main conditions necessary for the development of continuous design: 1) The construction of a systemic view of the production system by all actors; 2) The reinforcement of cooperative design learning; and 3) Training in new skills and institutionalizing these skills.

Studies in participatory ergonomics have shown positive results in terms of improvement of working conditions $[15,16]$. Participatory ergonomics is defined as the involvement of people in planning and controlling a significant amount of their own work activities, with sufficient knowledge and power to influence both processes and outcomes in order to achieve desirable goals [17]. This definition is relevant to the extensive use of participatory methods in workplace improvement [18].

In the line of the studies on participatory design and continuous improvement, the present study examines: 1) the functioning of kaizen groups in an assembly plant; 2) the role of operators in the continuous improvement of the work process; 3 ) the types of improvements achieved and 4) to what extent do kaizen groups integrate the improvement of working conditions.

The main objective of this study is to define the conditions for a real improvement of working conditions in a lean organization through kaizen process.

The point of view defended in study is that: kaizen groups aim to improve the work process by the reduction/elimination of non added value activities (Muda, Mura, Muri) by the operators who are integrated to the design process but the improvements are rather based on the prescription (the standardized work) than on the real activity. This leads to an increased pace of work and to the definition of rigid standards.

To investigate these issues, a methodology of study of the kaizen groups will be developed. This methodology includes a study of the kaizen process: its organization, the actors involved, the objectives presented; the role of the operator in the work process improvements; and an analysis of the results of the kaizen process.

Table 1

The team concept in North American transplants from the literature revue of Gough \& Fastenau (2003) [10]

\begin{tabular}{|c|c|c|}
\hline Plants studied & The ideology of the team concept & The practice of the team concept \\
\hline $\begin{array}{l}\text { CAMI Suzuki/GM } \\
\text { joint venture, On- } \\
\text { tario } \\
\text { Rinehart et al.1997 }\end{array}$ & $\begin{array}{l}\text { The kaizen concept is central to the ide- } \\
\text { ology that employees are empowered to } \\
\text { participate in the lean production system }\end{array}$ & $\begin{array}{l}84 \% \text { of employees (survey) considered that teams did not encour- } \\
\text { age commitment to the company. Management responses to kaizen } \\
\text { suggestions were perceived by employees as resulting in them having } \\
\text { to work harder rather than smarter. } \\
\text { Results of the kaizen groups } \\
\text { Heavier workloads, increased pace of work, loss of team members } \\
\text { and grater risk of injury. }\end{array}$ \\
\hline $\begin{array}{l}\text { Toyota Kentucky } \\
\text { Besser, } 1996\end{array}$ & $\begin{array}{l}\text { A "community of fate" in which em- } \\
\text { ployees and employer are joined }\end{array}$ & $\begin{array}{l}\text { The continuous improvement of the kaizen process appeared to } \\
\text { work well; employees were involved in numerous changes. } \\
\text { These favorable responses were undoubtedly related to the fact that } \\
\text { the plat was situated in an area of high unemployment. }\end{array}$ \\
\hline $\begin{array}{l}\text { Mazda Flat Rock, } \\
\text { Michigan } \\
\text { Babson, } 1995\end{array}$ & $\begin{array}{l}\text { Consensus decision making (Fucini \& } \\
\text { Fucini 1990) }\end{array}$ & $\begin{array}{l}72 \% \text { of the respondents (survey) believed that their supervisor rare- } \\
\text { ly implemented the company's philosophy of participatory manage- } \\
\text { ment. } \\
\text { Changes of the standardized work methods were imposed on em- } \\
\text { ployees. } 74 \% \text { of workers had their jobs sheets changed without being } \\
\text { consulted. } \\
\text { Results of the kaizen groups } \\
\text { For } 67 \% \text { of workers the changes made their jobs harder }\end{array}$ \\
\hline
\end{tabular}




\begin{tabular}{|c|c|c|}
\hline $\begin{array}{l}\text { Subaru-Isuzu (In- } \\
\text { diana) } \\
\text { Graham, } 1995\end{array}$ & $\begin{array}{l}\text { Every employee work as part of a team } \\
\text { to produce quality products. Management } \\
\text { committed to communicate with and listen } \\
\text { to employees. Employees are involved in } \\
\text { kaizen activities. }\end{array}$ & $\begin{array}{l}\text { Very little use of kaizen by team members. } \\
\text { Quality discussions worked to an agenda set by management. } \\
\text { Arbitrary decisions made by management without consulting em- } \\
\text { ployees. }\end{array}$ \\
\hline $\begin{array}{l}\text { NUMMI Toyo- } \\
\text { ta/GM joint ven- } \\
\text { ture, California } \\
\text { Adler, } 1992 \text {; Adler } \\
\text { et al. } 1997\end{array}$ & $\begin{array}{l}\text { Careful selection of managers with a } \\
\text { participative style and continuing attempts } \\
\text { to maintain open communication with } \\
\text { employees, employee suggestions for im- } \\
\text { provements }\end{array}$ & $\begin{array}{l}\text { Many of GM's former employees had experienced unemployment } \\
\text { or/and reduction in wages. } \\
\text { Peer pressure, low staffing levels and job security acted to ensure } \\
\text { compliance. }\end{array}$ \\
\hline
\end{tabular}

\section{Methods}

This study took place in an assembly plant in an automotive industry were lean production principles such as defined earlier were adopted. Three different vehicles models were assembled in the factory and each model had a multitude of possible combinations. Continuous improvement work groups "kaizen groups" had already existed in the past but in ways more or less different.

The analysis focused on two main phases of the kaizen groups: the functioning of the kaizen groups and the study of the improvements achieved by the group. The objectives of the kaizen groups were to improve the proportion of "value-added activities" (VA) as defined by lean production and working conditions, essentially physical constraints.

Seven kaizen groups were observed during the reconception activity of the work stations. Each work group lasted three hours and was piloted by a group leader. The groups were composed of three (three being the minimum required) to six persons including: the team members, team leaders, group leaders (of the morning and afternoon shifts) and a technician. These work groups were held during a period of two months (from September to November 2010). The researcher integrated those groups as a participative observer meaning that she did not propose changes or participate in decision making about the changes but she completed the various checklists specific to the kaizen group as all participants. Data were collected using paper and pencil note-taking. Even though participants knew the researcher, a cam recorder might have disrupted the functioning of the group. A general observation grid was built prior to the observations and included items such as: the participants (who, at what moment in time), the proposed changes, the expected gains, the accepted changes.

In parallel, activity at the workstations was filmed before and after the re-conception activity. The re- cordings were used to analyze the changes in work but also as cues for interviews with the employees concerned by the change. These interviews were made from several days to eight weeks (as the researcher had to consider the availability of the operators) after the kaizen groups once the changes on the work stations have been made. The interviews focused on the feedback of operators in relation to the kaizen groups and the changes made at their workstations. They were recorded and transcribed integrally.

Previous to the meeting of the kaizen groups, managers, operators and technicians were trained on the characteristics of a lean workstation. This training lasted four hours and was carried out at one time.

\section{Results}

In this section are presented the preliminary results of the study since it is still ongoing. Three main dimensions of the results based on the observations and the interviews will be addressed: 1) the organization of the work groups: that is the temporal organization, the initial preparation, the participants present in the groups; 2) the types of improvements proposed during the work group and the improvements achieved and 3) the feedback of the participants and in particular of the operators.

\subsection{The functioning of the kaizen group}

Each kaizen groups was conducted over a period of three hours, two kaizen groups were held each week in the area of the plant where the study was conducted. These work groups took place during working hours. In order that operators of both shifts (morning and afternoon) were present, operators from the morning shift had to stay longer and operators from the afternoon shift had to arrive earlier (this work time was consider overtime hours). 
The stages of the kaizen groups were defined in advance by the organization and methods department and described in an A3 sheet that was presented by the moderator each time to all participants at the beginning of the session. The moderator changed each time, it could be the group leader, the team leader or a technician, but it was always someone who had a very good knowledge of the workstation studied. That means that the person knew all the operations of the workstation but he could not always do the operations in the cycle time. Operators had never the position of moderators. In addition moderators had fallowed a short training about the characteristics of a "lean workstation" and about piloting kaizen groups.

The three main stages of the kaizen groups were: 1) presentation of the working method, in ten to twenty minutes, this included the presentation and the description of the supports for observing and analyzing the work stations. For example every participant had to fill a grid made to identify all non added value activities such as the walking limitations and the reduction of space, an "ergonomic constraints grid" (eighteen categories were informed) that had been filed by the group leader or the technician before the kaizen; 2) Observation of operators working in the workstation under study with the grids presented before. Each operator from the two shifts showed to the group his way of working and the group had to decide which one would be standardized... 3) After the observation period participants drew schemes of the new disposition of the work station and of the new trolleys used by the operators to move the parts of the vehicle to be installed. The participation of operators ended at this point. Further modifications were made by the technicians and maintenance workers.

\subsection{The types of improvements}

The term "improvements" is used from the lean work process perspective and refers to their performance criteria as described above. In the kaizen groups observed, these improvements were focused on the reduction and elimination of "non valueadded activities", also called "muda" from their Japanese name. These activities were: the reduction of work spaces, the limitations of movement going from limiting distances to the reduction of gestures needed to take and install parts in the vehicle.

Improvements of working conditions were focused on: lighten the trolleys, limiting painful posi- tions including work with the arms above the heart or bending. The ergonomic constraints grid was used in a limited way during observations. As described above, this grid had eighteen different items but only a very limited number were studied during the observations. In one case, an effort measure was made as the operator complained about the effort needed to push the trolley. In that case, an effort was made to redesign the trolley in order to make it lighter.

\subsection{Participants feedback}

Interviews were mainly conducted with operators. Two principal themes emerged from the interviews: managing change and the sharing of practices with colleagues.

Regarding managing change, operators found that changes took place too fast, beyond the kaizen group, they found that their workstations are modified too often which leaves them no time to get used to it. In addition most of the time these changes do not come on their own initiative but they are imposed.

Many operators highlighted the interest of discovering the strategies of their colleagues during the observation period in the kaizen group. Even if this didn't mean that they would adopt these strategies. The negative side was that during the work group they had no time to discuss these strategies.

\section{Discussion and conclusion}

The main objective of this study was to define the conditions for a real improvement of working conditions in a lean organization through kaizen process.

The point of view defended was that kaizen groups aim to improve the work process by the reduction/elimination of non-added value activities but the improvements are rather based on the prescription, the standard work, than on the real activity. This leads to an increased pace of work and to the definition of rigid standards.

These first results provide some data to this hypotheses and are consistent with the literature about accelerated forms of re-conception activities (for example Kaizen-blitz as describes by Toulouse et.al [8] where the objective is to find the solution for pre-determined production problem in only a few days showing that the predefined objectives cannot be discussed and employees have limited room for 
maneuver to elaborate solutions based on the analysis of their activity. Some authors qualified this practice as "controlled autonomy" [19]. As Caroly et al. [9] pointed out, rapid implementations of solutions is a criterion of effectiveness of the kaizen approach.

In the cases studied here the main issues concerns the objectives of the kaizen groups that were not discussed during the work group or elsewhere including the justification for changes and selection criteria to retain the "best practice" that was based on rigid grids for detecting "muda". Moreover, issues related to the collective and the fact that several operators are required to work in the same workstations (linked to shift work and job rotation) emerged in the interviews and in the observations. As pointed out below in the lean production philosophy the "best way" of working is defined by predetermined factors such as the speed of execution of tasks, the walking limitations and the reduction of movements. When it comes to redesigning a work station and define a new procedure this can become a source of conflict between operators whose practices are different. Issues on working conditions are only considered under the biomechanical aspect and variability of situations and diversity of people is very little taken into account. These results highlight the need for a questioning on organizational performance and on the place of the improvement of working conditions in the performance indicators.

The role of operators should be studied with a more systematic method in order to understand how they can contribute effectively to improve to the overall working conditions. For instance participation can studied and characterized as ranging from simple consultation to a real possibility of decision making and the possibility of challenging predefined objectives $[14,20]$. Specific data on age, sex, seniority and experience with participatory design methods is missing but it could bring up interesting facts about involvement in the kaizen process.

From these results the objective will be to propose improvements in the conduct of work groups and this at different stages going from the planning of work groups and the definition of objectives to the cooperation between operators after the work group in the line of continuous improvement as defined in the organization. Moreover as previous studies [9] have shown, the main challenge in the continuous design of work process is to integrate a global consideration of work, its hazards and its variability in order to identify the factors that pro- mote the improvement of working conditions and in particular the prevention of musculoskeletal disorders.

\section{References}

[1] J.P. Womack, D.T. Jones and D. Roos, The machine that changed the world, Free Press, New York, 2007 (first edition 1990)

[2] F. Bourgeois, O. Gonon, Le lean et l'activité humaine. Quel positionnement de l'ergonomie, convoquée par cette nouvelle doctrine de l'efficacité? Activités, 7 (1), (2010), 136-142

[3] F. Daniellou, Développement des TMS: désordre dans les organisations et fictions managériales. $2^{\text {ème }}$ congrès francophone sur les TMS - Montréal: IRSST, 2008

[4] E. Applebaum and R. Batt, The new American workplace: Transforming work systems in the United States. Ithaca, NY: ILR Press, 1994

[5] E. Lorenz, A.Valeyre, Les formes d'organisation du travail dans les pays de l'Union européenne, Travail et Emploi, 102, 91-105, 2005

[6] P.A Landsbergis, J. Cahill and P. Schnall, The impact of lean production and related new systems of work organization on worker health, Journal of Occupational Health Psychology, 4, (2), (1999), 108-130

[7] T.A. Saurin and C.L. Ferreira, The impacts of lean production on working conditions: A case study of a harvester assembly line in Brazil. International Journal of Industrial Ergonomics, 39, (2009) 403-412

[8] G. Toulouse, I. Nastasia and D.Imbeau, Etude de faisabilité en vue d'intégrer la santé et la sécurité du travail et l'ergonomie à l'approche PVA-Kaizen, Rapport R-428, IRSST, Montréal, 2005 www.irsst.qc.ca

[9] S.Caroly, F. Coutarel, E. Escriva, Y, J.M. Schweitzer and F. Daniellou, La prévention durable des TMS, quels freins, quels leviers d'action? Rapport à la Direction Générale du Travail, Paris, 2008

[10] R.Gough and M. Fastenau, Implementing different concepts of lean production: Workers experience of lean production in North American transplants, working paper series, Victoria University, 2003

[11] F. Darses, F, A cognitive analysis of collective decisionmaking in the participatory design process. $7^{\text {th }}$ Participatory Design Conference (pp.74-83). Malmö, Sweden, 2002

[12] F. Darses and M. Wolff,..How do designers represent to themselves the users' needs? Applied Ergonomics, 37, (2006)757-764.

[13] P. Falzon, Enabling safety: issues in design and continuous design. Cognitions Technology and Work, 10, 1, (2008) 7-14

[14] F. Darses, Trois conditions socio-techniques pour l'optimisation de la conception continue du système de production. Revue Française de Gestion Industrielle, 21, (1), (2002) 5-27

[15] M. St-Vincent, G. Toulouse and M. Bellemare, Démarches d'ergonomie participative pour réduire les risques de TMS: bilan d'expériences et pistes de recherche, Perspectives interdisciplinaires sur le travail et la santé (PISTES), 2, (1) 2000; http ://www.unites.uqam.ca/pistes/v2n1/articles/v2n1a5.htm

[16] M.Bellemare, S.Montreuil, M.Marier, J.Prévost and D.Allard, L'amélioration des situations de travail par l'ergonomie participative et la formation, 56, (3) (2001), 470-490 http://id.erudit.org/iderudit/000079ar 
[17] J.R. Wilson and H.N. Haines, Participatory ergonomics, in: Salvendy, G. (Ed.), Handbook of Human Factors and Ergonomics. Wiley, Chichester, 1997, pp.490-513

[18] K. Kogi, Participatory methods for ergonomic workplace improvement, Applied Ergonomics, 37, (2006), 547-554

[19] A. Valeyre, Conditions de travail et santé au travail des salariés de 1'Union Européenne: des situations contrastées selon les formes d'organisation (rapport technique) Centre d'Etudes de l'Emploi, 2006
[20] F. Darses, A framework for continuous design of production systems and its application in collective redesign of production line equipment. Human Factors and Ergonomics in Manufac-

2. 